\title{
Rethinking waste as a resource: insights from a low-income community in Accra, Ghana
}

\author{
Martin Oteng-Ababio
}

\begin{abstract}
Conventional solid waste management protocols and thinking generally tend to assume that waste already exits and therefore needs to be managed. Consequently, most models of solid waste management, especially in the developing countries including Ghana, are simply reactions to the presence of something that needs to be disposed of or discarded. This paper sees this conventional solid waste management philosophy as a potential barrier to an efficient and sustainable management and argues that adopting an integrated systemic approach will both help to control the processes that generate waste (including waste handling and utilization) and enable city managers to minimize waste generation in the first place. This paper uses a project initiated by a community-based organization in Ga Mashie (Accra) to explore the potential of converting household waste into a resource. Adopting a multiple research methodology, the study analyzes the characteristic and composition of waste generated within communities in Accra. The results show that a greater part of the 'waste' is recyclable or potentially recyclable and that a well-coordinated recycling programme will not only ensure a huge reduction of waste volume, but can equally lengthen the life of existing dumpsites and possibly, create wealth and reduce poverty. The paper argues that scaling up the project offers the local authority an opportunity to tap into the innovative strengths embedded in the project, particularly its physical and economic synergies, which may bolster community sustainable development.
\end{abstract}

Keywords: Environmental sanitation; Waste segregation; Resource; Poverty alleviation; Ga- Mashie

\section{Background}

"To waste, to destroy our natural resources, to skin and exhaust the land instead of using it so as to increase its usefulness, will result in undermining in the days of our children the very prosperity which we ought by right to hand down to them amplified and developed."

- Theodore Roosevelt, Seventh Annual Message,

December 3, 1907

The admonition from Roosevelt is an indication of society's long cherished dream of living in an environment of resourcefulness rather than wastefulness. Yet, as the world hurtles towards its urban future with the world's urban population increasing by two new people every second, and with 95 per cent of such increases taking place in cities of developing countries, nowhere is the impact more obvious than in society's "detritus," or solid

Correspondence: moababio@ug.edu.gh

Department of Geography and Resource Development, University of Ghana, Legon, Accra 00233, Ghana waste (Hoorneweg and Bhada-Tata 2012). Studies show that currently, cities cover only $2 \%$ of the world's surface but generate $70 \%$ of the world's waste (Zaaman and Lehman 2011). In Ghana, Accra produces conservatively 2,200 tonnes of solid waste daily, and is expected to reach 4,419 tonnes by 2030 (Oteng-Ababio 2010). The relationship between waste and cities is particularly threatening the future, in situation where practically everything is based on a throwaway mentality, which pays little regard to sustainability.

In countries where efficient solid waste management (SWM) policies have been instituted, including effective waste collection, segregation, transportation, storing, treatment and disposal, 'waste' is economically re-circulated (Medina 2005; Sternberg 2013). In such situations, SWM is not only seen as a necessary process to promote health and environmental safety, but also as presenting an opportunity to mine the largely untapped resources embedded in waste. The dilemma in Ghana is how to develop systems that can best utilize these inherent resources, even though the paper believes that the inability of city authorities to develop 
appropriate SWM policies cannot be wholly attributed to technical or economic reasons (see Grant and OtengAbabio 2012). It also has much to do with how waste is conceptualized and operationalized in the first place. Ojeda-Benitez et al. (2000) re-emphasizes the point when she opines that to appreciate the value of 'waste', it must be differentiated from refuse. To her, refuse refers to a situation where different kinds of waste are disposed of or mixed together in the same container, causing unpleasant odour and pollution, making it impossible for re-use. However, when kept separately with a minimum of order and care, such materials become waste to the original owner but may have some value for other persons.

In recent times, it appears that people's socio-cultural practices or throwaway mentality, where activities are designed to take 'resources', make products and turn them into waste ('take-make-waste' attitude) are impacting negatively on the ecosystems, particularly with increasing population, improved technology and increased consumption. At the same time, waste is also becoming so diverse in its origin and forms, and so pervasive in its impacts, through terrestrial, aquatic, and atmospheric ecosystems that it has the potential to adversely affect both the inhabited and uninhabited parts of the world. The penchant of state officials also to unilaterally accept foreign SWM prescriptions during their international conferences, regardless of local technical or socio-economic circumstances and expecting overnight transformations, has worsened matters (see Ali 2010). The inherent uncertainty about 'local therapies' is part of an age-long debate but such tendency stifles local innovative resourcefulness. It also brings UN Sustainability City Program into question as per the present 'take-make-waste' attitude, neither industry nor the consumer has any incentive to use resources frugally. This creates chronic environmental concerns and pushes cities to grow in a disorderly manner, causing an accumulation of urban problems.

It is beyond the scope of this paper to venture into the debate on "the limits to growth" vis-à-vis resource consumption or the negative environmental impacts that will occur from wastes generated by an increasingly consumerist urban population. That said, the fear about these effects is warranted, particularly since nearly $95 \%$ of environmental damage occurs before a product is discarded as solid waste (Hoorneweg and Bhada-Tata 2012). This paper intends to shift the current emphasis from the "end-of-the-pipe approach", where waste is collected and disposed of (without any incentive to recycle), towards encouraging consumption within the waste stream. It is believed that most waste materials can cascade through a series of uses that can enhance job creation, decrease the need for 'natural resources' and eventually, the overall waste flows.

In what follows, the paper discusses the notion of waste and its value chain, highlighting on its implications for urban livelihoods and sustainable environmental management. Particular reference is given to the activities of a local non-governmental organization (NGO), Great Thinkers' Club, which has pioneered a youth enterprise from recycling of solid waste generated in James Town, a low-income community in Accra. The paper draws on the value chain thinking, demonstrating how the project has been designed synergistically to produce employment for the youth, through a range of valuable by-products of waste while, at the same time ensuring efficient SWM. Finally, the paper proposes a paradigm shift, which is intended to help all project stakeholders to appreciate waste as a resource.

\section{The notion of waste and the value chain}

\section{Waste is waste?}

Waste, otherwise termed rubbish, trash, junk or garbage depending on the type of material, or the region in question, is a complex, subjective and perhaps controversial issue. Though waste is generally seen as an unwanted or undesired material and a bothersome problem and sometimes, a health threat if improperly treated, it can in some cases, generate good business for some, when properly handled. The complexity of waste manifests in the difficulty and multiplicity of its definition and description, which is also contingent on who is looking at the subject matter: ordinary citizens, technicians, businessmen, politicians, activists (Progracz 2002). Since different approaches have been used in defining waste, it is notably a challenge to gather comparable data for example, between waste in rich and poor countries. Table 1 presents some definitions of waste.

These definitions do not resolve the uncertainties surrounding what waste is. What runs through them, however, is the fact that waste is something that its holder has disposed of or discarded. This creates the problem of distinguishing between 'dispose of' and discard, as both principally mean getting rid of. Cheyne and Purdue (1995), however, suggest that disposal is a deliberate and thoughtful act to put something in a suitable place (either for sales, transfer of ownership, etc), while discard implies outright rejection, with or without interest in its final destination, since that thing is seen as useless or undesirable.

Other studies (CEFIC 1995) also argue that it is not the nature of the material that determines whether it is a 'waste, but the actions or intentions of the holder. Therefore, only those materials for which the holder has no further use and which he discards or intends to discard are waste. Lox (1994) also see waste as "either an output with (a negative market) no economic value from an industrial system or any substance or object that has been used for its intended purpose (or served its intended function) by the consumer and will not be reused". This definition also appears deficient, since the last part of it creates an impression that 
Table 1 List of definitions of waste

\begin{tabular}{|c|c|c|}
\hline Organization & Definition & Source \\
\hline Eionet & $\begin{array}{l}\text { Waste includes all items that people no longer have any use for, which they } \\
\text { either intend to get rid of or have already discarded. Wastes are such items } \\
\text { which people are required to discard, for example by lay because of their } \\
\text { hazardous properties. }\end{array}$ & http://scp.eionet.europa.eu/themes/waste \\
\hline Full cycle & $\begin{array}{l}\text { Waste, or rubbish, trash, junk, garbage, depending on the type of material is } \\
\text { an unwanted or undesired material or substance. It consists of unwanted } \\
\text { materials left over from a manufacturing process or from community and } \\
\text { household activities. }\end{array}$ & $\begin{array}{l}\text { http://www.fullcycle.co.za/index.php/what-is- } \\
\text { waste-and-why-is-it-a-problem.html }\end{array}$ \\
\hline Basel convention & $\begin{array}{l}\text { Wastes are substances or objects which are disposed or are intended to be } \\
\text { disposed or are required to be disposed of by the provisions of national } \\
\text { laws. }\end{array}$ & $\begin{array}{l}\text { http://www.basel.int/Portals/4/Basel\% } \\
\text { 20Convention/docs/text/ } \\
\text { BaselConventionText-e.pdf }\end{array}$ \\
\hline $\begin{array}{l}\text { UN Statistics } \\
\text { Division }\end{array}$ & $\begin{array}{l}\text { Wastes are materials that are not prime products (that is products produced } \\
\text { for the market) for which the generator has no further use in terms of his/ } \\
\text { her own purposes of production, transformation or consumption, and of } \\
\text { which he/she wants to dispose }\end{array}$ & $\begin{array}{l}\text { http://unstats.un.org/unsd/environment/ } \\
\text { wastetreatment.htm }\end{array}$ \\
\hline EU & $\begin{array}{l}\text { Waste is any substance or object which the holder discards or is required to } \\
\text { discard }\end{array}$ & $\begin{array}{l}\text { http://ec.europa.eu/environment/waste/pdf/ } \\
\text { WASTE\%20BROCHURE. }\end{array}$ \\
\hline OECD & Wastes are materials other than radioactive materials intended for disposal & http://www.oecd.org/env/waste/ \\
\hline UNEP & $\begin{array}{l}\text { Wastes are substances or objects, which are disposed of or are intended to } \\
\text { be disposed of or are required to be disposed of by the provisions of } \\
\text { national law }\end{array}$ & $\begin{array}{l}\text { http://www.unep.org/greeneconomy/Portals/ } \\
\text { 88/documents/ger/GER_8_Waste.pdf }\end{array}$ \\
\hline European EPA & $\begin{array}{l}\text { Waste is any substance, which constitutes scrap materials or any effluent or } \\
\text { other unwanted surplus substance arising from the application of a process } \\
\text { or any substance or article, which requires to be disposed of as being } \\
\text { broken, worn-out, contaminated or otherwise spoiled. }\end{array}$ & $\begin{array}{l}\text { http://www.nwcpo.ie/forms/EWC_code_book. } \\
\text { pdf }\end{array}$ \\
\hline $\begin{array}{l}\text { Institute of safety } \\
\text { Professionals } \\
\text { (Nigeria) }\end{array}$ & $\begin{array}{l}\text { Waste is when something is no longer useful to the owner or it is used of } \\
\text { fails to fulfill its purpose. }\end{array}$ & http://www.eco-web.com/edi/090901.html \\
\hline
\end{tabular}

a product is designed for a single purpose and therefore, as soon as the purpose is fulfilled, it turns to waste.

Gourlay (1992) exemplifies this deficiency using a dollop of mustard left on a plate, which he argues is neither useless nor lost its properties and queries if such a material only became waste just because the owner failed to use it. In his contribution to unravel the puzzle, Gourlay proposes a working definition for waste as "what we do not want or fail to use". However, his definition also appears more humanrelated and fails to properly account for the concept of production wastes, especially the issue of by-products that are not necessarily created from carelessness but unavoidably emanating from the production process itself.

Contributing to the debate, Stanbury (2005) attribute the complexity of the term waste to its genesis, which they traced to the Latin word uastus and which evinces several meanings; to ravage, to leave desolate or cultivate. To them, waste connotes inefficiency and mirrors situations where managers of entities fail to minimize cost or maximize output because they are not using the best technology available. Elwood and Patashik (1993) add another dimension when they blithely asserted that waste, like beauty, is in the eye of the beholder. It can thus be argued that since there is no such thing as waste in nature, then waste is a human concept. Within the ecosystem, recycling is rife, hence production and decomposition are well balanced and ensure stability and sustainability in natural systems.

Human engagement with the ecosystem, however, places much emphasis on its economic value, resulting in situations where production and consumption become the dominant activities. Such a system tends to be highly destructive, consuming massive natural capital and energy, which return into the environment as waste, requiring even more natural capital to be consumed in order to feed the system (Pongracz 2002). The presence of waste is therefore an indication of overconsumption and inefficient use of resources, since the capacity of the natural environment to absorb and process these materials is finite and the improper waste disposal results in the loss of valuable resources. From all indications, the main problem confronting most developing countries is the sheer volume of waste being produced and how 'waste' is conceptualized.

\section{Re-defining solid waste management}

Significantly, the goal of any legislation on waste is to protect the environment and public health. Consequently, the conventional SWM hierarchy adopted by most local authorities and their donor agencies includes a 5-staged process, involving waste reduction, re-use, recycle, incinerate, and safe disposal of the residual at landfills (Forbes 
et al. 2001). From that perspective, this paper re-affirms that waste and its management involves multi-faceted activities and processes, yet opines that an efficient SWM should include the supervision of such operations and maintenance of disposal sites, which the current hierarchy appears silent. The present models implicitly assume that waste already exists "in space" and needs to be managed and that, SWM is simply a reaction to the presence of something that needs to be eliminated.

Seeing waste with that lens may create a barrier to an efficient and sustainable SWM system and may negatively affect the overall decision related to the transport, reuse, and sale of materials. Conversely, this paper believes that preventing the accumulation of waste from the beginning maximizes resource efficiency and sustainable management. An optimal approach to SWM would be an integrative system-based approach that provides control over processes that generate waste, waste handling, and waste utilisation (IPCC 2007). Thus, the key to any effective SWM involves waste minimization that helps the reduction of the amount of things to be disposed of, and this includes:

- Preventing and/or reducing the generation of waste at source;

- Improving the quality of waste generated, such as reducing the hazard, and,

- Encouraging re-use, recycling and recovery.

It is important to stress that minimizing the amount of things intended for disposal is only one of the options of waste minimization, which then reinforces the perception that 'the wasted thing' is already there to be disposed of. This contravenes the principal meaning of waste minimization, which is to avoid waste generation in the first place (Pongracz 2002). By inference, waste can be seen as a value concept, culturally construed, very subjective and may implicitly have a remote economic value.

Most developed countries have adopted the philosophy of waste minimization as the menu for their SWM systems, but scarcely has this informed policies in developing countries, where pressures of urbanization, land space for waste disposal and wanton destruction of natural resources are creating a bigger challenge (Baud et al. 2001). In Ghana, the individual local authorities (assemblies) are charged with the responsibility to manage waste in their respective jurisdiction and must do so in the most economically, socially and environmentally optimal manner possible (MLGRD 1999). Prior studies (Post and Obirih-Opareh 2002; OtengAbabio et al. 2013) have shown that waste management remains the single largest item on the assemblies' budget yet the most pernicious local pollutant (uncollected waste remains the leading contributor to local flooding and pollution). Equally important challenge confronting most authorities relates to their inability to appreciate waste as a resource as to date, and, as a consequence, waste separation remains alien or not properly address due to lack of finances. Even the National Environment and Sanitation Policy of 1996, and revised in 2010, remains loudly silent on waste minimization, creating a waste industry that is vague, dysfunctional and disjointed.

Earlier studies (see Hetherington 2004; Gregson et al. 2007; Adama 2012; Thieme 2013) highlight the fact that urban poverty and waste picking are inextricably linked with the urban poor engaging in scavenging as a survivalist strategy while at the same time, filling the vacuum created by the public sector-led SWM operations. There are also enough evidence showing that historically, communities have been resourceful to use waste as food for animals, fertilizer and as materials for second life products (Wilson et al. 2006). These studies point to a vibrant waste enterprise, devoid of policy or legislative, often tedious, unhygienic, unrecognized and potentially hazardous, whose contributions are rarely documented or quantified. These activities rank lowest in the waste recycling rung and participants are mostly the urban poor, especially women and children (Ahmed and Ali 2006). This paper is hopeful that more lessons can be gleaned from such informal operations in our quest for economically and environmentally cost effective SWM. Figure 1 establishes tractable pathways of making waste a resource through waste segregation at source, based on the value chain concept.

On a broader scale, waste segregation reduces the burden of waste collection and disposal, minimizing loads of waste that need to be transported to dump sites. At the household level, there is need for capacity building on ways to reduce the amount of generated waste and these include recycling and re-using products. 'Re-use' involves using the product more than once for the same or a different purpose. Composting is also a good way of disposing of biodegradable waste materials, especially in residential areas and can provide compost for urban agriculture and create more local jobs. This paper believes that if municipal waste is to be harnessed to improve livelihoods, then government and its agencies must necessarily develop efficient markets and build a knowledge base around "what works".

\section{Research location and methodology The study area}

To achieve the set goals, the study adopted multiple survey methods including key informant's interviews, participant observation and a comprehensive review of official and other documents to generate empirical data. The research was conducted in Accra, the political capital of Ghana, which also serves as its administrative, socio-economic and cultural hub, harbouring about $70 \%$ of all manufacturing activities (Grant 2009; Owusu et al. 2008). The research location is Ga Mashie (also called old Accra), the spiritual 


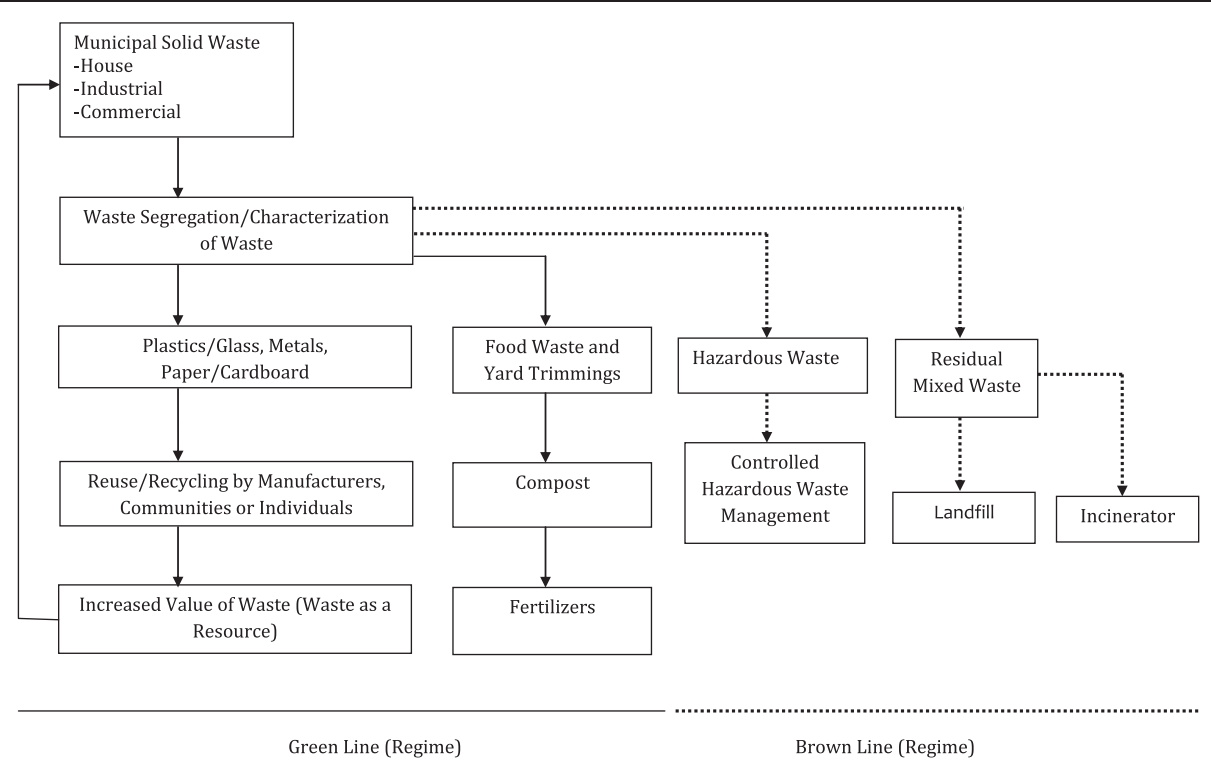

Figure 1 Pathways for managing waste as a resource (ISWM). Source: Author's construct.

home of the Ga people, with a youthful population of about 100,000, mainly engaged in fishing (CHF International 2010). Living off fishing and trading, Ga Mashie (see Figure 2) is sub-divided into James Town or British Accra and Ussher Town or Dutch Accra. The community is one of the poorest in Accra, with the highest education level of majority being senior high school or its equivalent (UNHabitat 2010). This is reflected in the area's poverty levels, recording an average monthly income of GH4 126.13 or USD $78.83^{\mathrm{a}}$, against a regional (Greater Accra) average of

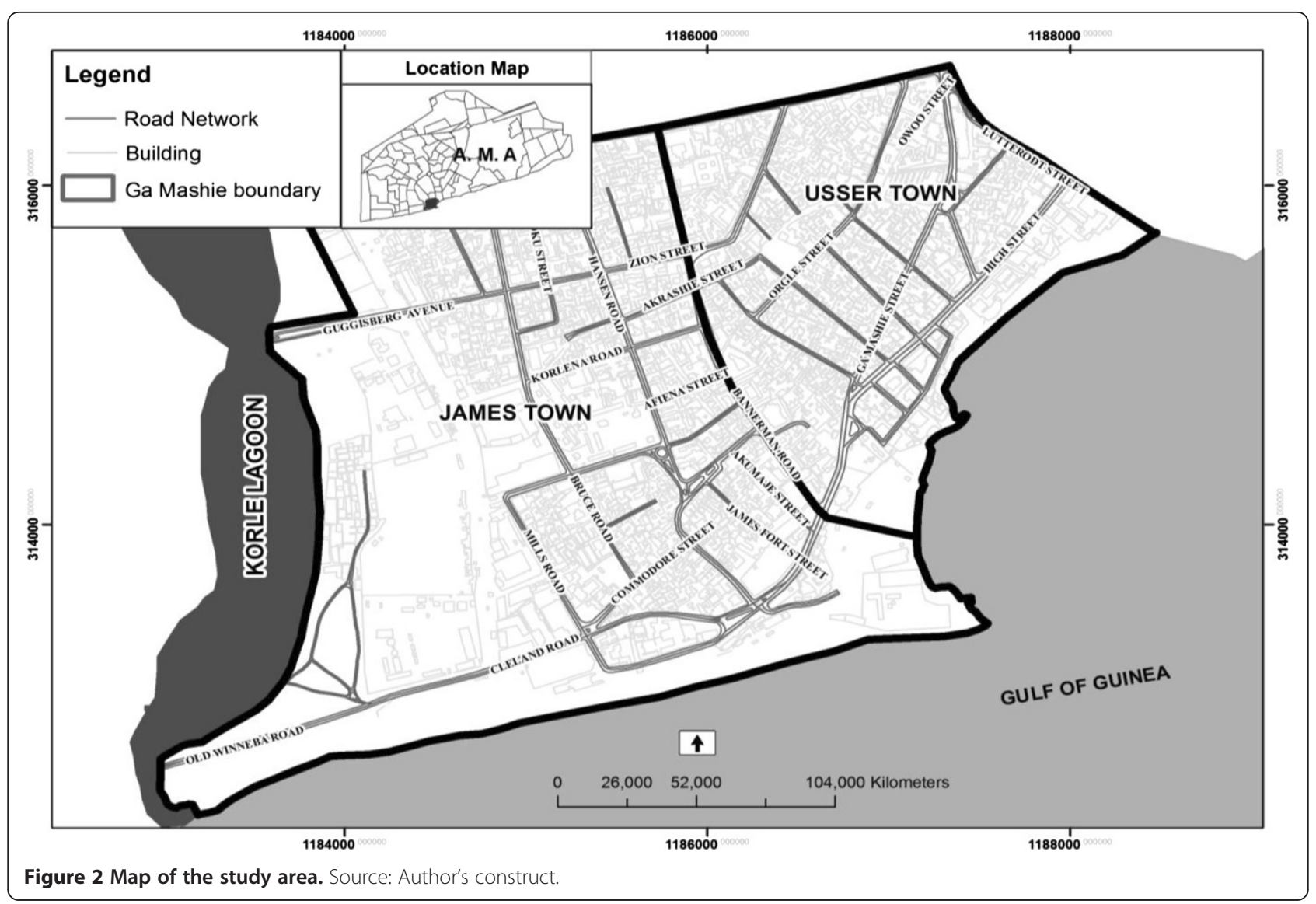


GH\$ 544.00 or USD 340.00 (GSS Ghana Statistical Service 2008). The average number of people per house stands at 48 , or 7 people per room, against 5.1 at the regional level (CHF International 2010).

\section{Waste generation in Accra}

Waste is the most visible by-product of a resourceintensive, consumer-based economic lifestyle. Its generation rate is a function of population and affluence (Hoornweg and Bhoda-Tata 2012) with richer societies characterized by higher rates of waste generation per capita, while less affluent societies generate less waste and tend to practice informal recycling and/or re-use initiatives that reduce the waste per capita to be collected at the municipal level. In SubSaharan Africa, about 62 million tonnes of waste is generated annually with an average rate of $0.65 \mathrm{~kg} /$ capita/day (Hoornweg and Thomas 1999). In Accra, the correct waste generation rates and its characteristics are non-existent or questionable at best since there has not been any comprehensive waste audit since 1993. Consequently, various sources give conflicting figures: $0.51 \mathrm{~kg} / \mathrm{day}$, (MLGRD 1999), $0.41 \mathrm{~kg} /$ day (WRI 2007) and $0.81 \mathrm{~kg} /$ day (CHF International 2010). Such discrepancies in figures serve as potential impediment to proper planning and this must be taken into consideration in interpreting. Table 2 presents projected municipal waste scenario by 2030 .

The data show increasing waste generation so is the backlog and by inference, unsightly environment. According to Post and Obirih-Opareh (2002), there is a direct relationship between the method of waste collection and environmental sanitation, with residents using the container system clearly disadvantaged, dissatisfied and disappointed. Meanwhile studies have shown that for health reasons, the organic nature of waste in tropical regions like Ghana makes it imperative that it is actually collected daily. This makes the challenges and costs of SWM even more daunting. In Accra, it is generally the city center and the wealthier neighbourhoods that receive service when it is available (see Oteng-Ababio 2010). In poorer areas, uncollected wastes accumulate at roadsides, are burned by residents, or are disposed of in illegal dumps, which blight neighborhoods and harm public health (Huober 2010).

Table 2 Estimated waste generation of Accra (2000-2030)

\begin{tabular}{ccccc}
\hline Years & Population & $\begin{array}{c}\text { Waste } \\
\text { generation } \\
\text { (Tons/Day) }\end{array}$ & $\begin{array}{c}\text { Waste } \\
\text { collection } \\
\text { (Tons/Day) }\end{array}$ & $\begin{array}{c}\text { Residual } \\
\text { (Tons/Day) }\end{array}$ \\
\hline 2000 & $1,658,939$ & 2,127 & 1,702 & 425 \\
2005 & $1,960,797$ & 3,369 & 2,695 & 674 \\
2010 & $2,317,583$ & 2,654 & 2,123 & 531 \\
2020 & $3,237,730$ & 3,390 & 2,712 & 678 \\
2030 & $4,523,203$ & 4,419 & 3,535 & 884 \\
\hline
\end{tabular}

In neighbourhood like James Town, roadside accumulation "has reached levels resembling those that spawned epidemics in European cities 500 years ago" (see EGSSAA 2009: 2; Melara, et al 2013), with its impacts not routinely monitored or virtually ignored. On few occasions where attempts have been made to improve dumpsites management, these often tend to be in reaction to threats of their imminent closure by nearby communities. Unless more effective urban SWM programs and public water supply systems are put in place, outbreaks of cholera, typhoid and plague may become increasingly common.

\section{Waste characterization}

Waste composition of any community is influenced by its geographic location, level of economic development, cultural norms, energy sources, and climate, among others. As countries urbanize and population becomes wealthier, consumption of inorganic materials (plastics, paper, aluminum) increases, while the organic fraction decreases. The study examined a number of baseline surveys (see Table 3) to compute the waste composition, since no official data exists. In all instances, proper permission was sought, including appropriate ethical clearance (No ECH 061/13-14) approved by Institute for Statistical, Social and Economic Research (ISSER), University of Ghana, Legon. The findings yielded an average organic component of $67.68 \%$, but the high rate of illegal disposal in drainages, river channels and open spaces raises lots of concern (Oteng-Ababio 2010).

Be that as it may, the findings show that with efficient institutional arrangements, political will and appropriate infrastructure investment and human resource, most of the household waste can receive value addition. Unfortunately, until the advent of the project of the Great Thinkers' Club in James Town, separation and treatment of organic waste was very rare. While the recovery and reuse of materials was generally for personal use, there were many 'professional' waste pickers - popularly called 'Kaya bola' in the local parlance, whose activities were seriously threatened by disease organisms, sharp objects and other hazards in the waste. They generally lacked protective equipment a situation that is a clear manifestation of the extent of poverty in the neighbourhood.

\section{Case description}

\section{Overview of Great Thinkers' Club activities}

Studies (Medina 2005; Sternberg 2013) have noted that the adverse impacts of SWM are best addressed by establishing integrated programs where all types of waste and all facets of the waste management process are considered together. Though desirable, limited resources normally prevent these programs from being implemented, and only a piecemeal solution tend to be possible. The "Great Thinkers' Club" changed this dynamics in the study area by initiating and developing an integrated SWM system and building of the 
Table 3 Waste characteristics/ Waste stream analysis

\begin{tabular}{|c|c|c|c|c|c|c|}
\hline Type of Waste & Zone $A^{1}(\%)$ & Zone $\mathrm{B}^{1}(\%)$ & Zone $\mathrm{C}^{1}(\%)$ & $\mathrm{Nima}^{2}(\%)$ & Jamestown $^{2}(\%)$ & Newtown $^{3}(\%)$ \\
\hline Organic & 74 & 71 & 78 & 56 & 60 & 67 \\
\hline Plastic & 10 & 8 & 6 & 17 & 16 & 20 \\
\hline Paper & 5 & 5 & 4 & 2 & 1 & 4 \\
\hline Metal & 4 & 4 & 4 & 5 & 5 & 2 \\
\hline Glass & 2 & 1 & 0 & 2 & 2 & 2 \\
\hline Textiles & 1 & 1 & 1 & 9 & 6 & 5 \\
\hline Inert & 4 & 7 & 5 & & & \\
\hline Others & & 3 & 2 & 3 & 1 & \\
\hline
\end{tabular}

Source: 1-Dagadu, (2007); 2-Kumashie I, (2011); and 3-Earth Institute, (2010).

Zone A: High-income, low-density waste zone (Cantonments, Airport Residential Areas).

Zone B: Middle-income, medium-density waste zone (Adabraka; Kaneshie).

Zone C: Low-income, high-density waste zone (James Town, Nima).

technical, financial, and administrative capacity of the community to manage and sustain it. Suffice to add that whether pursued holistically or in a piecemeal faction, waste managers must ensure that the program is appropriately tailored to local conditions and that the practical environmental, social, economic, and political needs and realities are balanced.

As the waste audit indicated, a large part of household waste in Accra is potentially recyclable as organic waste accounts for about $60 \%$, while paper and other inorganic recyclables (glass, tin) are fairly represented. Yet, this opportunity remains poorly unexplored. Indeed, within the city, a compost plant built in 1976 at Teshie (another suburb of Accra), with a processing capacity of 200 tonnes a day was decommissioned in 2002 due to operational difficulties (see Oteng-Ababio et al. 2013). In particular, lack of source separation of waste greatly affected its operations. Thus, the NGO's activities demonstrate a bold attempt to both tap into the untapped potential embedded in waste and help advance that scholarship in the area of environmental sustainability.

Broadly, the NGO is a youth community-based organisation established in 1999 in Ga Mashie, a suburb with poor sanitation and rising youth unemployment (UN-Habitat 2011). Its mission includes increasing opportunities to enrich and address youth community needs. With a membership of 100, the club's activities span from maintaining efficient environmental sanitation to a recently instituted youth employment through SWM. The funds for the current project, dubbed Youth Engagement in Service delivery (YES) was secured through Co-operative Housing Foundation (CHF) International under the Bill and Melinda Gates Foundation. The project involves a 4-value chain process of municipal waste (biodegradable organic fractions; metals; plastics; electronic waste or e-waste).

The project was initiated with a dual dividend strategy: to engage the beleaguered youth in gainful employment through the provision of environmental services. As part of the project, a house-to-house waste collection, which hitherto was the preserve of only rich neighbourhoods in the city, was introduced at Ga-Mashie in place of the poorly managed container collection system (Kumashie 2011). Using local resources, teams from the local NGO were selected, trained and equipped to provide house-to-house waste collection services to households who willingly agreed to register with the group. Each youth was equipped with a tricycle, nose masks, safety boots, safety overall, and hand gloves (see Figure 3) provided with sponsorship from CHF international (see CHF International 2010). With the exception of the tricycle, all other equipment and training were provided at no cost to participants. The tricycle however was given to participants on a hire-purchase scheme under which each waste collector was to pay cumulatively GH4600, (US\$310), which beneficiaries unanimously agreed to pay in nine months (i.e. GHC 63 [US\$ 32.57] a month).

The project, which also had a plastic recycling enterprise (Trashy Bags) and a community compost plant, incorporates two rational SWM principles: it encourages source separation of waste and embodies the polluter-payprinciples. At the time of the research, a total of 770 households or $33 \%$ of total households in the study area were covered under the project. Each registered household is given two waste bins with which to separate organic and inorganic waste. Each household is also encouraged to separate plastics, waste electrical and electronic equipment (WEEE) and metals. The bins are given for free as a way of motivating participants to undertake source separation of waste (minimise waste), which is seen as the bedrock of any sustainable SWM system. The waste collectors have the responsibility to collect the segregated organic waste daily for onward transfer to the community compost plant.

It is important to add that the quality of compost produced by the YES project was scientifically certified by Ghana Standards Board and has been successfully piloted by some vegetable farmers in Accra (CHF International 


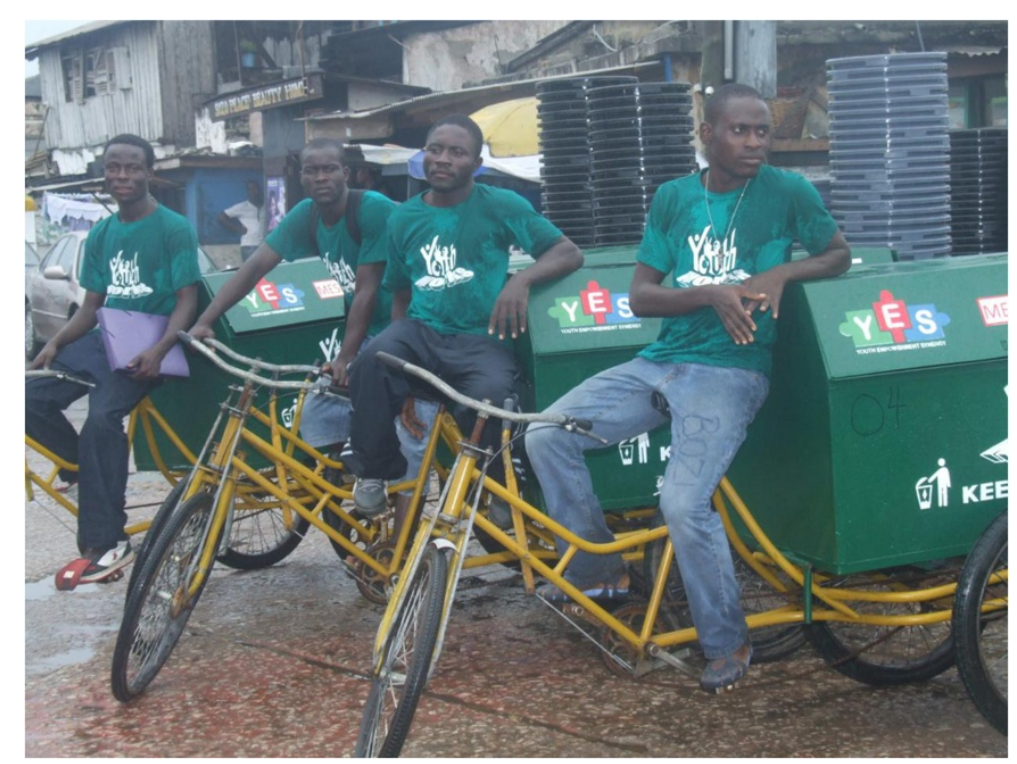

Figure 3 Youth team with their tricycles on the house-to-house waste collection operation. Source: Field work, 2013.

2010). Accordingly, the waste behaviour (composition) and the subsequent certification of end-product give a glimmer of hope; the possibility of converting the huge organic waste into compost and thereby, ensuring safer, liveable environment. Its actualization however needs commitment and participation of all stakeholders - government, local authorities, service providers and beneficiaries. Currently, a private company, Zoomlion Ghana Limited, has initiated a waste recycling project; Accra Compost and Recycling Plant Limited. However, the lack of source separation has compelled the company to be very selective in where to pick waste for recycling, (i.e. only high-income areas), where there is little likelihood of waste contamination with fecal matter, which could be as high as 10\% (see Kumashie I 2011).

\section{The collection and analysis}

The fieldwork involves qualitative data collection that took place between August and November 2012. It consisted of personal observation, focus group discussions (FGDs), and semi-structured interviews with 25 key informants, including the executives of the local NGO, service beneficiaries and participants, 5 community opinion leaders including the assembly man and the leaders of 2 prominent women groups. Some public officials from the Municipal Assembly, Ministries of Local Government and Rural Development, and Gender, Children and Social Welfare as well as a representative of project sponsors were also interviewed. Specifically, the key informants were interrogated on the structure, prospects and challenges of the project, how the transformation of perceived waste into some value and the marketability of the products occurs, and present a more nuanced account of the value chain than the over- simplified end-of-pipe approach. Answers were also sought for the role of the NGO as well as the relationship among the local authorities, the NGO and the local community.

To assess the modus operandi of the NGO, participant observation was employed to learn at first-hand, how the club engages with the community and how it strategizes to outwit the authority's most "preferred" players - formal waste collectors. Two separate FGDs were organized between the beneficiaries and the NGO; and secondly, between the NGO and the representatives of the local authority with the sole aim of gathering in-depth understanding of the structure, processes and human behaviour and the reason governing such behaviour. The FGDs were held in the community, had nine participants each and explored issues bothering on efficiency, power relations and affordability of the services.

Participants discussed the project's challenges, proffered solutions and the possibility of scaling up the project. All submissions were recorded, later transcribed and thematically analyzed. To ensure unrestricted access to the NGO's project sites, their commitment was secured through the well-respected Assemblyman, re-enforced by the intervention of a local sub-chief who happens to be an "environmentalist" and has great passion for a good environment. The study benefitted immensely from earlier works, which engage with the challenges of managing waste in lowincome communities (Huober 2010; Matter et al. 2013).

\section{Discussion and evaluation}

Tapping the untapped potentials in waste: reflections from James Town

The YES Project waste flow is depicted in Figure 4 and falls in tandem with the government's 'privatization' 


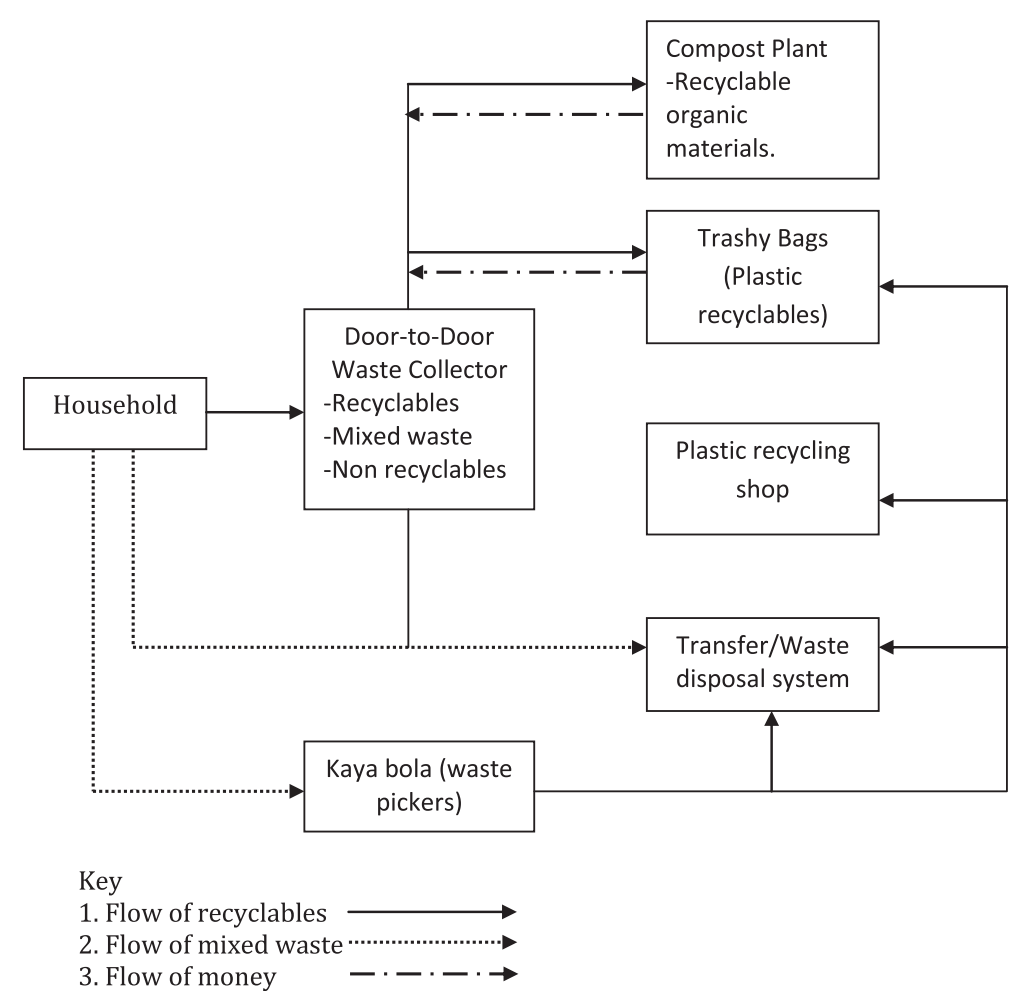

Figure 4 Schematic Overview of the YES Waste Management System. Source: Author's construct.

agenda which, in principle, involves gradually disassociating state-owned enterprises or state-provided services from government control and subsidies, and replacing them with market-driven entities (Grant 2009). In the context of municipal services, the process generally implies reducing local government activity within a given sector by: involving participation from the private sector including NGOS; or reducing government ownership, through divestiture of enterprises to unregulated private ownership, and commercialization of local government agencies.

In the case of the YES project, which is an example of community participation in SWM, the study shows that each participating household is encouraged to separate both recyclables (either organic, plastics, metals) and nonrecyclables. Generally, some of the recyclables (plastics, WEEE, and metals) are sold directly at the household level to prospective itinerant waste buyers who roam the community on daily basis, while the mixed waste and organic materials are collected by the trained community waste pickers for a fee. These service providers haul waste from registered household sources to the composting facility. This is effectively carried out by pre-collection services using the tricycles acquired through the YES project.

According to the system set up by the project and agreed upon by all stakeholders, a household pays between 10p (US\$0.05) and GHC 1 (US\$0.50) upon a visit by a waste picker depending on the volume of waste available at the time. The waste collector collects (isolates) the organic materials for onward delivery to the compost plant. The waste picker sends collected mixed waste to the transfer stations (mainly communal skips at sanitary sites), where a disposal fee of between GHC1 (US\$ 0.50) - GHC2 (US\$ 1.00) is paid. During the FGDs, beneficiaries most of whom work in the informal economy, lauded the project's affordability and flexibility "pay-as-you-go" billing system against the formal system which operates a monthly billing option. The NGO has the responsibility of providing a training environment to participants (capacity building) and explain repeatedly the basic concepts and principles upon which the project is founded to the community at large.

\section{The waste value chain: plastics recyclables and compost facility}

Results from the waste audit show that since 1993, there have been a gradual reduction in the proportion of organic materials, but a corresponding increase in plastics, increasing from $1.3 \%$ in 1993 to $3.5 \%$ in 2010 (Oteng-Ababio 2012). The increasing presence of plastics is attributed to the upsurge in the use of polythene bags for take-away food orders and water sachet bags (see Fobil et al. 2005). It is in recognition of this increase that the NGO established a plastic recycling enterprise (Trashy Bags) and trained some of its members to use thin films collected from the 


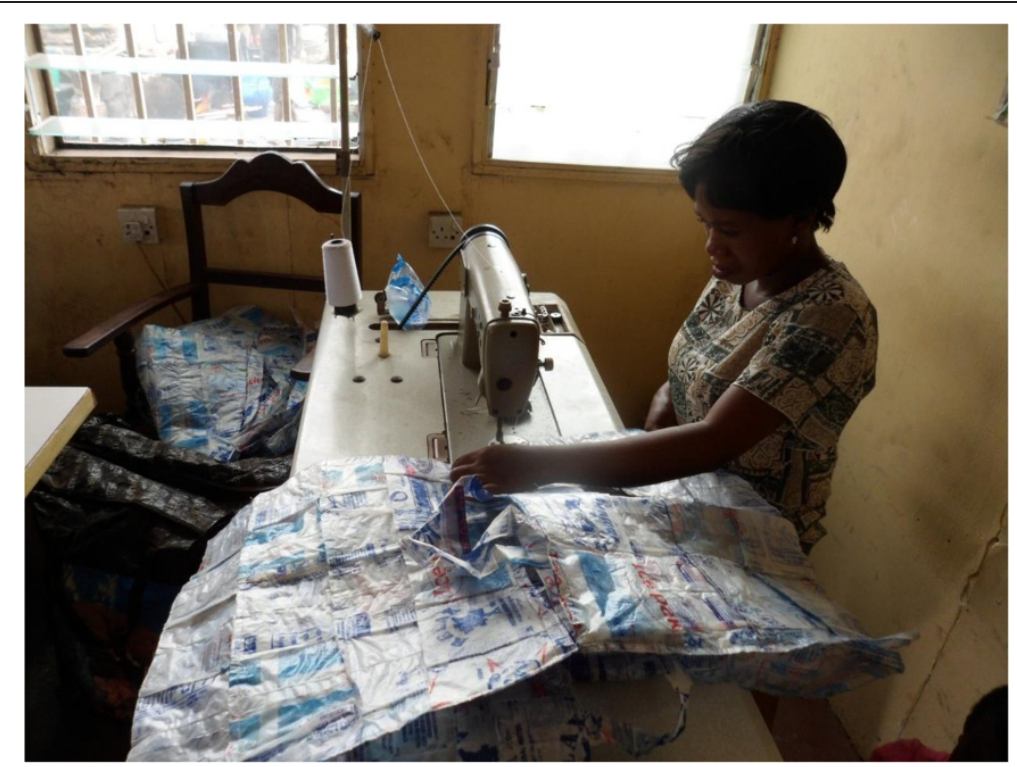

Figure $\mathbf{5}$ Recycling of thin plastics. Source: Field work, 2013.

community as feedstock to produce handbags, traveling bags, raincoats, jackets, etc (see Figure 5). The study reveals that 'waste' plastics are bought from members at $\mathrm{GH} 40.05$ for 500 pieces of clean ice cream sachets $(250 \mathrm{ml})$ and $\mathrm{GH}$ क $0.30 \mathrm{p}$ per kilo for empty water sachets $(500 \mathrm{ml})$.

Personal observations during the fieldwork confirmed increased presence of plastic waste and how it has been indiscriminately disposed in the drains and other open places. Thus, the move by the project presents positive indicators or economic incentives inherent in thin plastic recycling that the city authority can capitalize on to encourage source separation and minimize the current waste menace. This position was reinforced when it was revealed during the study that 7 new plastic waste purchasing outlets have emerged within the community since the commencement of the project. Indeed, Post and Obirih-Opareh (2002) intimate that most plastic industries operating in the city struggle to get feedstock to meet their installed capacity.

Similarly, the NGO has constructed a community compost plant in the community at the cost of US\$22,000 (CHF International 2010). The plant feeds into the employment motivation agenda of the project and creates a synergy between waste collection and disposal. The compost plant operators have also been trained on compost method and facility management as well as occupational safety and health procedures. The facility uses organic waste from the community and the processing of compost normally takes four (4) months (Figure 6).

In terms of profitability analysis, waste picking is an informal activity organized on an individual basis and therefore quantifying the actual labour costs incurred to enable one perform proper cost-benefit analysis is quite daunting, if not impossible. However, during the FGDs, participants in the plastic waste chain claim they earn between $\mathrm{GH} 40.20$ and GHc 0.35 per kilo or between GHc 8.20 and GHc 10.20 daily depending on the level of foreign materials (contaminants), which at the upper end, is 95\% higher than the national minimum daily wage of GH\& 5.24. By inference, each participant collects on average in excess of 20 kilos of plastic waste daily, emphasizing the project's potential not only to generate income but more importantly, contributing to a cleaner and healthier environment.

Concerning the compost facility, the challenge participants identified during the study relates to lack of sustained market for the end product. Prior scholarship had identified potential market to include i) real estate developers - using compost as soil conditioner in landscaping; ii) vegetable farmers - for nursing vegetables, and iii) Waste Management Department (WMD) for disposal operations - as capping material to reduce malodors. Meanwhile, at the time the Teshie plant was decommissioned in 2002, the price of a tonne of compost was just GH42 (US\$1.43) . After almost a decade, the market price at a private facility (Zoomlion, Ghana Limited) is GH\$30 (US\$ 15.5), indicating an increasing opportunity should the question of marketability be resolved (Matter et al. 2013).

On the part of the local government authorities, all respondents from the public service alluded to the fact that the project is a microcosm of what government stands to gain by encouraging community participation in service delivery. They opine that such a process leaves municipal resources available for other equally important urban infrastructure and equipment. The Head of WMD of the assembly asserted, "privatization of such urban services reduces the cost of public services to consumers; relieves the financial and administrative burden on the assembly; 


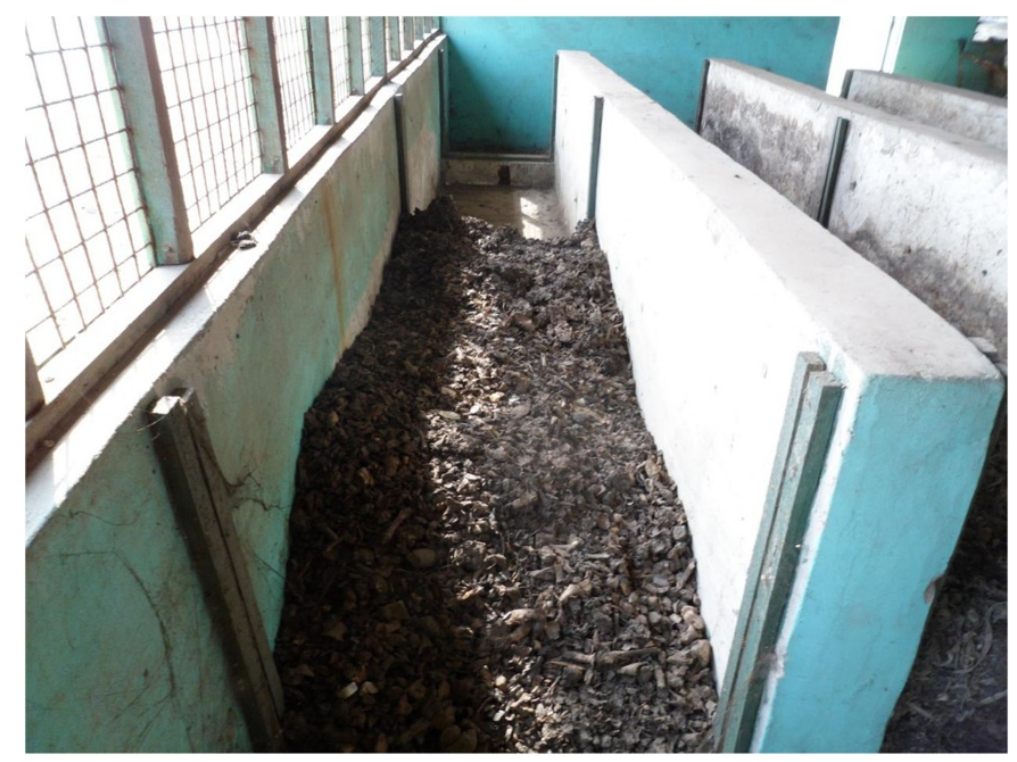

Figure 6 A compost facility showing the processing of waste into manure. Source: Field work, 2013.

increases productivity and efficiency by promoting competition; stimulates the adoption of innovation and new technology; improves the maintenance of equipment; and creates greater responsiveness to cost control measures".

A representative of the local government ministry reveals that community management of service provision as demonstrated by the YES project, is the highest level of community participation, and gives the community authority and control over operation, management and/or maintenance services benefiting its members. He however maintains that such partnership requires institutional support and recognition in order to be successful, which in this case both the Accra Metropolitan Assembly (AMA) and the local government ministry have shown and demonstrated enough commitment.

At the community level, a participant alluded to how the project has ensured a clean environment, as according to him, they could easily identify those who clandestinely litter the environment by the type of waste. An opinion leader also described the project as "important and innovative" emphasizing, "the use of community members to execute community service provides jobs, minimizes crime, poverty, rowdyism and also improves community communication and fosters social acceptability and participation". He called on the local authorities to 'dream' of scaling-up the project into a citywide system than creating new, parallel structures.

\section{Sustainability of YES Project: Is the Youth In Agriculture Project the answer?}

The Youth in Agriculture Programme (YIAP), which is a public sector commercial entity, initiated by Ghana government in 2006, seeks to motivate the youth into farming. As part of the incentives, the government provides certain services - land preparation, provision of seedlings, fertilizers, market opportunities, etc. In the 2010 national budget statement, the government declared financial commitment of GH\$2 million (US\$1.034 m) mainly for procuring seedlings and fertilizers (MOFA 2012). Given the huge debt the assembly incurs (accumulates) in disposing waste and equally huge funds government commits into procuring organic fertilizers, strategically scaling-up the YES project perhaps, provides an opportunity to address the marketability problem facing the YES compost industry. This is imperative not only because of the paucity of locations for dumpsites, but the possibility of building an engineered landfill anytime soon appears economically a remote possibility. Even in cases where donor support has been secured for such construction, poor planning results in community protestations and resistances (Oteng-Ababio 2010; Owusu et al. 2011).

Meanwhile, critical spatial analysis of the YES chain of activities shows that the city can take advantage of its physical and economic synergies and scale it up, particularly in lowincome communities within the metropolis where majority remains severely underserved when it comes to waste management services. Currently, the assembly remains heavily indebted to private service providers, standing at $\mathrm{GH} \$ 100$ million (US\$ $51.7 \mathrm{~m}$ ) by the end of 2011. Additionally, the disposal charge ${ }^{\mathrm{c}}$ of GHष12 (US\$ 6.2) per tonne is an indication of potential cost savings that can accrue to the city if alternative options for value-addition are identified. The YES project has demonstrated that a sizable portion of what is thrown away as "waste" contains valuable resources such as metals, glass, paper and plastics which can be reprocessed as raw materials. Constrained by mounting 
national debts in the face of many competing needs and tepid economic growth rates, the assembly will continue to bear more responsibility in managing its public affairs with limited resources. Thus, building greater cooperation will not only help manage the 'waste' sustainability but also provide an avenue for job creation and by extension, poverty reduction.

Assuming that the national economic realities are not going to change in the short-term, then it becomes necessary to adopt consumption and waste management practices that reduce the amount of waste destined for disposal or to be discarded. In other words, envisioning waste as a resource will extend the current dump's life, reduce the pressure on areas needed for new dumpsites while at the same time, creates employment. The role of local authorities in this direction is critical and indeed indispensable. Even interventions at household levels also benefit from involving the local authorities, who are the overall entity that have the responsibility for municipal SWM and represent public interest, to enhance legitimacy, support and acceptance or for up-scaling the initiative.

In summation, the study has demonstrated that establishing an integrated SWM system including waste separation at source, resource recovery and composting of organic waste, at least at the local level such as the YES project, requires representation of waste pickers (Kaya bola) and integration of the community to work with all stakeholders, including representatives of waste pickers. It also shows that in such community-led service delivery, local leaders are often active in management or maintain close contact with the municipality or community management body. Additionally, women and teens can play crucial roles, such as initiators, managers, operators, educators, and watchdogs for the community. In other words, encouraging community-based management of service delivery may help address certain social and management problems in SWM - low participation of household, management and operational problems, financial difficulties, and lack of municipal cooperation and capacity building.

\section{Conclusions}

The study re-affirms the position that a global depletion of natural resources leads to a global competition for resources and therefore the future competitiveness and vulnerability of cities are dictated by cities' ability to shift to a less resourceintensive production and way of life, with less waste generation and increased recycling (EU 2011). Clearly, there is a compelling need to reduce the volume of waste destined for dumpsites in Accra. The city authorities' apparent addiction to 'landfilling' is damaging for the environment and a manifestation of our failure to see waste as a potential resource. The situation in Accra may not be an isolated case, as most cities countrywide lag behind in terms of policy and practice. The religious enforcement of some 'by-laws' such as the "pay-as-you-dump" policy, which were seemingly enacted without reference to local knowledge, is tantamount to punishing the public. Rather, attempts should be made to give residents incentives to do the right thing and the YES project is a microcosm of such a model.

The project has amply demonstrated that awareness creation amongst all key stakeholder groups, including local government officials, NGOs and the public, is imperative for effective and sustainable SWM services, and that there is a wide range of methods used to raise awareness. It is however, important to choose the communication channels and materials that are appropriate for each target audience and for the specific situation of the municipality. It also building the capacity and adequately equipping participants as waste management, especially landfill operations, is highly technical and normally requires people with specific technical skills and sound scientific background. Benchmarking SWM functions and knowing what expertise is required to perform these functions will assist in drafting appropriate job descriptions and specifications.

By investing and cultivating the interest, enthusiasm and willingness of residents, and adopting acceptable socioeconomic initiative-based models that sustainably increase volumes of waste separated at source and recycled, the project has been extremely successful. It demonstrates that putting in place appropriate mechanisms to ensure a reliable and timely waste collection regime and an easy, stress-free, accessible and economical market for recyclables is critical for sustainable SWM system. This is of great importance in Accra, where municipal SWM poses a considerable environmental risk because waste is merely collected and buried with no engineered landfills.

Admittedly, such programmes will not be effective without concurrent community campaigns on the collection and sale of recyclables. Again, the negative preconceptions of city managers and planners about the informal economy in general, play an important inhibiting role in attaining integrated SWM system and this situation needs to be addressed. Seeing informality as a symptom rather than a victim of poor policies and programmes crowds out its inherent potentials, which can be gleaned to ensure sustainable environmental development. Appreciating the waste value chain means that all stakeholders ought to be made part of the governance structure.

Municipal SWM requires planning, foresight and reflexive governance to ensure that sustainable systems are adding value and/or complementary to each other (see Oteng-Ababio 2013). The current situation, where some urban residents are often prevented from participating and benefiting from the development processes and services because of their perceived lack of knowledge, or due to others' lack of knowledge about their situation, conditions and development needs, must be abated. Once knowledge and information is cultivated at the local level, accessed 
and shared, such tendency can place the community on an equal footing (Veeravatnanond et al. 2012). Such knowledge can be usefully shared between cities, improving prospects for pro-poor investments and development.

Efforts directed towards empirical research must continue, especially regarding waste audits since these will greatly support any future decision by city authorities. It is important to sample other areas to ascertain the possibility of replicating the YES project. In addition, waste separation programme must be accompanied by proper education to create deeper understanding in each community regarding separation, re-using and recycling activities so that the exercise is not simply regarded as tedious one imposed by 'bureaucratic, profit-making government authorities'. Rather, the process will be seen as a new approach that encourages residents to regard waste as a potential resource. The findings resonate with earlier studies (UN-Habitat 2011) that have shown that urbanization of poverty would increase unless the governance structure improve urban planning and management, and recognize the right of urban poor to improve their conditions and participate in the distribution of the benefits that the urbanization process has to offer.

\section{Endnotes}

${ }^{\mathrm{a}}$ In 2012, the exchange rate of a cedi to dollar stood at US\$ 0.517 .

${ }^{\mathrm{b}}$ In year 2000, the exchange rate of a cedi to dollar was US\$ 0.715 .

${ }^{\mathrm{c}}$ The private contractors charge a disposal fee of GHष 12 per tonne and with no weighing bridges installed at these sites, city authorities are at the mercy of both haulers and managers of the sites.

\section{Competing interests}

The author declares that he has no competing interests.

Received: 24 November 2013 Accepted: 15 April 2014 Published: 25 June 2014

\section{References}

Adama O (2012) Urban governance and spatial inequality in service delivery: a case study of solid waste management in Abuja, Nigeria. Waste Manag Res 30(9):991-998

Ahmed SA, Ali SM (2006) People as partners: facilitating people's participation in public-private partnerships for solid waste management. Habitat Int'l 30:781-796

Ali A (2010) Wasting time on solid waste in developing countries. Waste Manag 30:1437-1438

Baud I, Grafakos S, Hordijk M, Post J (2001) Quality of life and alliances in solid waste management contributions to urban sustainable development. Cities 18(1):3-12

CEFIC (1995) Discussion paper on the definition of waste, European Chemical Industry Council. 22 Feb 1995, http://www.cefic.org/position/Tad/pp_ta029. htm (3. Sept. 2002)

Cheyne I, Purdue M (1995) Fitting definition to purpose: The search for a satisfactory definition of waste. Journal of Environmental Law 7(2):149.168

CHF International (2010) Accra Poverty Map: A Guide to Urban Poverty Reduction in Accra. CHF International, Accra, Ghana

Dagadu PK (2007) Municipal Solid Waste Source Separation at the Household Level A Case Study of the Accra Metropolitan Area. An Unpublished Mphil Thesis submitted to the Institute of Environment and Sanitation Studies, University of Ghana
Earth Institute (2010) Millennium Cities Initiative Report: Findings of Waste Composition Study for Ayidiki Electoral Area, Accra, Ghana, Report by Earth Institute at Columbia University. New York, and University of Ghana, Legon

Elwood JH, Patashik E (1993) In praise of pork. Public Interest 132(Summer):19.33

Environmental Guidelines for Small-Scale Activities in Africa (EGSSAA) (2009) Solid waste: generation, handling, treatment and disposal, EGSSAA: Municipal Solid Waste/ March 2009/ EXCERPT. p 7, www.encapafrica.org

EU (2011) Challenges, Visions, Way Forward. European Commission, Directorate General for Regional Policy. Brussels, doi:10.2776/41803

Fobil JN, Carboo D, Armah NA (2005) Evaluation of municipal solid waste (MSW for utilisation in energy production in developing countries. Int'I I of Env and Tech Manag 5:76-86

Forbes DL, McLean RF, Tsyban A, Burkett V, Codignott JO, Mimura N, Ittekkot V (2001) "Coastal Zones and Marine Ecosystems." 264 Geography Reader. In: James J, Canziani MOF, Leary NA, Dokken DJ, White KS (eds) Climate Change 2001: Impacts, Adaptation, and Vulnerability. Contribution of Working Group II to the Third Assessment Report of the Intergovernmental Panel on Climate Change. Cambridge University Press, UK, pp 343-379

Gourlay KA (1992) World of Waste: Dilemmas of industrial development. Zed Books Ltd, London

Grant R (2009) Globalizing City: The Urban and Economic Transformation of Accra. Syracuse University Press, Ghana

Grant R, Oteng-Ababio M (2012) Mapping the invisible and real African economy: urban e-waste circuitry. Urban Geog 33(1):1-21

Gregson N, Metcalfe A, Crewe L (2007) Moving things along: the conduits and practices of divestment in consumption. Trans of the Inst of Brit Geog 32:187-200

GSS (Ghana Statistical Service) (2008) Ghana Living Standards Survey. Report of the Fifth Round (GLSS 5). Accra, Ghana

Hetherington K (2004) Secondhandedness: consumption, disposal, and absent presence. Env and Plan D: Soc and Space 22:157-173

Hoornweg D, Bhada-Tata P (2012) What a Waste: A Global Review of Solid Waste Management, Urban Development Series Knowledge Papers 68135, World Bank

Hoornweg D, Thomas L (1999) What A Waste: Solid Waste Management in Asia, East Asia and Pacific Region. Urban and Local Government Working Paper, World Bank, Washington DC, USA

Huober AL (2010) Moving Towards Sustainable Solid Waste Management in Accra: Bridging the Formal-Informal Divide. Dissertation, Amherst College

Intergovernmental Panel on Climate Change (IPCC) (2007) Climate Change 2007: The Physical Science Basis. In: Solomon S, Qin D, Manning M, Chen Z, Marquis M, Averyt KB, Tignor M, Miller HL (eds) Contribution of Working Group I to the Fourth Assessment Report of the Intergovernmental Panel on Climate Change. Cambridge University Press, New York

Kumashie I (2011) Municipal Solid Waste Management in the Accra Metropolitan Assembly: The Case of The Communal Container Collection System. An unpublished Mphil Thesis submitted to the Institute of Environment and Sanitation Studies, University of Ghana

Lox F (1994) Waste Management. Life Cycle Analysis of Packaging. Final Report. Vlaamse Instelling voor Technologisch Onderzoek, Belgian Packaging Institute, for the European Commission, DG XI/A/4, Consortium Vrije Universiteit Brussel

Matter A, Dietschi M, Zurbrugg C (2013) Improving the informal recycling sector through segregation of waste in the household - the case of Dhaka, Bangladesh. Habitat Int'l 38:150-156

Medina M (2005) Serving the unserved: informal refuse collection in Mexico. Waste Manag 23:390-397

Melara JE, Grant R, Oteng-Ababio M, Ayele B (2013) Downgrading - an overlooked reality in African cities: reflections from an indigenous neighborhood of Accra, Ghana. App Geog 36:23-30

MLGRD (Ministry of Local Government and Rural Development) (1999) National Environmental Sanitation Policy. Ministry of Local Government and Rural Development, Accra

MoFA, MoFA (Ministry of food and Agriculture) (2012) Annual Report on Draft MoFA Strategic Plan for 2013-2015, Ghana. Unpublished data from various directorates' internal reports

Ojeda-Benitez S, Armijode-Vega C, Ramirez-Barreto E (2000) The potential for recycling of household waste: a case study from Mexicali, Mexico. Environ and Urb 12(2):163-173

Oteng-Ababio M (2010) Private sector involvement in solid waste management in Ghana: the case of the Greater Accra Metropolitan Area (GAMA). Waste Manag and Res 28(4):322-329

Oteng-Ababio M (2012) The role of the informal sector in solid waste management in the GAMA, Ghana: challenges and opportunities. Tijdschrift voor Economische en Sociale Geografie 103(4):412-25 
Oteng-Ababio M (2013) Unscripted (in) justice: unequal exposure to ecological hazards in Metropolitan Accra. J of Enviro and Plan A 45(5):1199-1218

Oteng-Ababio M, Melara JE, Gabbay O (2013) Solid waste management in African cities: sorting the facts from the fads in Accra, Ghana. Habitat Int'I 39:96-104

Owusu G, Agyei-Mensah S, Lund R (2008) Slums of hope and slums of despair: mobility and livelihoods in Nima, Accra. Norsk Geografisk Tidsskrift. Norwegian J of Geog 62:180-190

Owusu G, Oteng-Ababio M, Afutu-Kotey LR (2011) Conflicts and governance of landfills in a developing country city, Accra. Lan and Urb Plan 104(2012):105-113

Pongracz E (2002) Re-defining the concepts of waste and waste management: Evolving the theory of waste management. Academic Dissertation to be presented with the assent of the Faculty of Technology, University of Oulu

Post J, Obirih-Opareh N (2002) Quality assessment of public and private modes of solid waste collection in Accra, Ghana. Habitat Int'I 26:95-112

Stanbury W (1995) Toward a political economy of government waste: First step, definitions. Public Administration Review 55(5):418-427

Sternberg CA (2013) From "cartoneros" to "recolectores urbanos": the changing rhetoric and urban waste management policies in neoliberal Buenos Aires. Geoforum 48:187-195

Thieme AT (2013) The 'hustle' among youth entrepreneurs in Mathare's informal waste economy. Journal of Eastern African Studies 7(3):389-412

UN-Habitat (2010) Collection of Municipal Solid Waste in Developing Countries. United Nations Centre for Human Settlements

UN-Habitat (2011) Ghana Housing Profile. United Nations Human Settlements Programme. UNON, publishing services section, Nairobi, ISBN 978-92-1-132416-7

Veeravatnanond V, Nasa-Arn S, Nithimongkonchai W, Wongpho B, Phookung K (2012) Development of risk assurance criteria to the utilization of natural resources and environment for sustainable development of life quality, economy and society in rural Thai communities. Asian Soc Sci 8(2):189-195, February 2012

Wilson DC, Velis C, Cheeseman C (2006) Role of informal sector recycling in waste management in developing countries. Habitat Int'l 30(4):797-808

WRI (Water Research Institute) (2007) Assessment of the greater Accra water resources monitoring for sustainable management. Water Research Institute, Accra

Zaaman AU, Lehman S (2011) Challenges and opportunities in transferring a city into a 'zero waste city'. Challenges 2(4):73-93

doi:10.1186/2195-2701-1-10

Cite this article as: Oteng-Ababio: Rethinking waste as a resource: insights from a low-income community in Accra, Ghana. City, Territory and Architecture 2014 1:10.

\section{Submit your manuscript to a SpringerOpen ${ }^{\circ}$ journal and benefit from:}

- Convenient online submission

- Rigorous peer review

- Immediate publication on acceptance

- Open access: articles freely available online

- High visibility within the field

- Retaining the copyright to your article

Submit your next manuscript at $\gg$ springeropen.com 